\title{
Fiscal Implication of Agrarian Reform Program to the Real Property Tax Collection in Negros Occidental
}

\author{
Sharon M. Zaragoza ${ }^{1}$ and Merlita V. Caelian ${ }^{2}$ \\ ${ }^{1}$ Provincial Government of Negros Occidental, Bacolod City, Philippines \\ ${ }^{2}$ University of Negros Occidental-Recoletos, Bacolod City, Philippines
}

\begin{abstract}
Article history:
Submitted: 27 October 2020

Revised: 17 December 2020

Accepted: 31 December 2020
\end{abstract}

\section{Keywords:}

Public administration

Property taxation

Agrarian reform program

Fiscal implication

Descriptive-correlational

Negros Occidental

Philippines
ABSTRACT. Property taxation is a component of land governance policies, processes, and institutions that relies on a land administration system, efficient property market, and secure legal rights. This study assessed the fiscal implication of the Comprehensive Agrarian Reform Program (CARP) in the real property tax (RPT) collection when municipalities are grouped by income classification, size of the area, and land classification. This descriptive-comparative and correlational research used secondary data and a checklist administered to 19 treasurers of a first-class province. Using descriptive and inferential analyses, the study yielded "very great" negative fiscal implications. No significant differences were found when municipalities were grouped as to income and size but a significant difference when areas were identified by classification. There is a significant relationship between the fiscal implication and the size of the area covered. The respondents encountered challenges. The study recommends revenue generation strategies, legislative support, and livelihood for agrarian beneficiaries.

\subsection{Introduction}

Property taxes are imposed in every country in the world as part of a balanced system of taxation (International Association of Assessing Officers, 2010). Differences in socio-political aspirations, perceptions and traditions, infrastructures, resources, history, needs, and culture all affect the type of property tax that will or will not work for the stakeholders (UN-HABITAT, 2011).

In the ASEAN region, countries lagged behind the global average in terms of tax revenues collected as a proportion of gross domestic product, which means that the ASEAN government must explore ways to leverage fiscal policy for sustainable growth. In the context of the Philippines, real property taxation is vested with the provincial, city, and municipal governments within the Metropolitan Manila Area (MMA). Outside the MMA, provinces collect the tax but delegate this function to local treasurers (Guevarra, 2004). The Local Government Code of 1991 enumerated the subjects of real property taxation as lands, buildings, machinery, and improvements; hence, agrarian reform beneficiaries as owners of lands, are liable to pay real property taxes on lands awarded to them through the CARP.

Studies were conducted on the taxation of agricultural lands. Agricultural taxation, tax structure, the taxable base, and tax rates for farmers were studied by Soliwoda and Tyszko (2015). Cvjetkovic, Veselinovic, and Nikolic (2015) discovered the privileged treatment of farmers on taxation, while McDonnell, Foukona, and Pollard (2011) explored the success of the government in land reform. Several authors such as Rajaraman (2005) and Cvjetkovic et al. (2015) agreed that agriculture is the sector that is very difficult to tax. In the Philippines, Villaroman (2017) studied the factors affecting collections of real property taxes. Cruz and Cruz (2018) assessed the revenue-raising capacity of LGUs. The only study found conducted in Negros Occidental focused on the CARP covered properties was that of Lorayna and Caelian (2020) but on the participation of civil society organizations on the implementation of CARP.

Of the studies reviewed, no study focused on the fiscal implications of the policies and mechanisms of CARP to the RPT collections of municipalities; thus, this study will determine the fiscal implications and the differences when municipalities are grouped by income, size of areas covered, and land classification to fill the gap in the literature and to contribute to the body of knowledge on property taxation. The findings of this study will be used as a basis in the formulation of strategies to address the fiscal implications of the agrarian reform program.

\subsection{Framework of the Study}

This paper theorizes that agrarian reform policies have negative fiscal implications for the collection of real property taxes of LGUs. The study is anchored on the theory of optimal taxation of 
Ramsey (1927) and Mirrless (1971) that espoused distributive and distortionary effects of particular policies. This theory posits that it is subject to a set of constraints for a tax system to maximize a social welfare function. This theory is appropriate in this study as it will determine the impact of the policies and mechanisms in the agrarian reform program, whose objective is a social welfare function but is subject to the rules and regulations of local government taxation. The study will examine the distributive and distortionary effects of the CARP on collecting real property taxes, which is the lifeblood of local governments.

Further, the study is also anchored on the theory of distributive justice on taxation by Aristotle. According to this theory, taxes on private property are significant to the government as they fund social services. However, too much taxes imposed where the goals of efficiency and accountability take precedence over the values of the welfare state will create discontent, and people will refuse payment resulting in higher tax delinquencies. Therefore, to strike the right balance between efficiency and equality, the marginal tax rate must be tailored to taxpayers' ability to pay. This will be explored in this study in collecting real property taxes on properties covered by the CARP. The CARP distribution of lands to landless farmers aligned with the advocacy of Aristotle for equality where the inferior are not living under insufficiency. This theory seeks equitability that will be determined with bigger areas covered by CARP, translating to higher collectibles of real property taxes. The study will unravel how local governments enforced legislation of real property taxation to achieve equality through the strategies employed by local treasurers to collect taxes on agrarian covered properties. The framework will determine whether there is a relationship between the extent of fiscal implications of CARP policies with the size of the landholdings covered by the agrarian program, whether fiscal implications will depend on the size of the landholdings covered.

Finally, the study will attempt to integrate the benefits and the horizontal equity principles to the optimal theory that a person's tax liability should be related to the benefits that he receives from the government and that same groups of people should pay similar tax burdens. The findings of the study will be used as baseline information in the formulation of revenue generation strategies to address fiscal implications.

\subsection{Methods}

The study used a descriptive-comparative and correlational research design. A descriptive research design is utilized to describe the extent of fiscal implications of the agrarian reform program on collections of real property taxes. This is appropriate, considering the directions of the study, which aimed to describe a situation or a given state of affairs in terms of specified variables (Johnson \& Kuby, 2012). The study also utilizes the comparative design to examine the differences of the fiscal implications when the municipalities are grouped by income, the size of the area covered, and land classification. It will use a correlational design to determine if a relationship exists between the fiscal implications with the size of the area covered by CARP. The respondents of the study are the total enumeration of the 19 municipalities represented by their municipal treasurers.

Secondary data will be used to determine the fiscal implications. In contrast, a checklist shall be used to determine the challenges and strategies employed by treasurers in collecting taxes. Fiscal implications will be measured using the collection efficiency formula adopted from the Department of Finance (DOF). A scale of interpretation provides a collection efficiency of below $85 \%$ as a "very great extent," which means that the fiscal implications of CARP policies are significantly substantial to RPT collections. The lowest rating in the scale is a collection efficiency of $100 \%$ and up interpreted as a very low extent of fiscal implications.

To answer the problem, which seeks to determine the extent of fiscal implications of CARP in the collections of real property taxes, the mean was used. Normality test using Kolmogorov-Smirnov showed that the variables fiscal implications and the size of the area covered are not normally distributed. Hence, nonparametric statistical tools were used for comparative and correlational analyses. Kruskal-Wallis was used to determine the significant differences in the extent of fiscal implications when municipalities were grouped by variables. Spearman rank correlation was used to determine the significant relationship between the fiscal implications of CARP with the size of the area covered. On the challenges encountered and strategies employed by treasurers, frequency, and percentage were used. 


\subsection{Results and Discussion}

\section{Extent of fiscal implications of CARP policies to RPT collections}

Fiscal implications refer to the negative or positive influence of the agrarian reform policies on collecting real property taxes in the municipalities.

Table 1 presents the fiscal implications of the agrarian reform policies to the RPT collection of the municipalities as a whole as "very great" $(M=4.68$; $S D=6.23)$, which means that the agrarian reform program has a significant negative substantial effect on the collections of real property taxes of the municipalities. This is revealed by the collection efficiency of below $85 \%$ of total tax collectibles. The highest collection efficiency for the period $2014-2018$ was $12.90 \%$, interpreted as a "very great" negative extent of fiscal implication. This means that $87.10 \%$ of taxes are not collected. It was further revealed that the total real property taxes that were not collected on covered agrarian properties was One Billion Eight Hundred Forty-Three Million Ninety-Six Thousand Two Hundred and Seventeen \& 08/100 (Php1,843,096,217.08). This finding is supportive of the study of Cruz and Cruz (2018) that the collection efficiency of an LGU in the country is almost $20 \%$ of the total collectibles and that $80 \%$ of taxes are not collected.

Findings affirmed the study of Guevarra (2004) that the land reform program has made the collection of the tax more difficult in the Philippines. Likewise, the study of Ballesteros (2010) concluded that land reform had become a major burden on LGUs. Also, many problems were alleged to have been caused by unclear and inconsistent land policy, highly politicized land tax system, and inefficient agrarian reform program (Llanto \& Ballesteros, 2003). Spoor (2012) substantiated these findings of very great negative fiscal implications on RPT collection, revealing that the growing inequality and widespread rural poverty were outcomes of agrarian transformation.

The lowest collection efficiency for $2014-2018$ was $0.71 \%$ or less than $1 \%$ of real property taxes collectible from agrarian covered properties, which is a very significant negative fiscal implication. This finding strengthened the studies of Balisacan (2007), Sauer (2009), Borras et al. (2009), Spoor (2012), and De los Reyes (2016) that one of the greatest problems in LGUs is the collection of taxes on CARP. The issuance of collective certificates of land ownership awards (CLOA) is one of the major causes of no payment of real property taxes; hence, this mechanism has substantial negative fiscal implication on revenue of LGUs. Also, challenges faced by the program as articulated in the study of Drbohlav et al. (2017), such as opposition from landlords, criticism by civil society, cynicism by legislators, lack of financial and material resources, and general public apathy are contributing to difficulties in the program translating to non-payment of real property taxes by agrarian beneficiaries.

Income classification. When municipalities are grouped as to income classification, which refers to the assigned classification of LGUs used as a factor in the allocation of national and other financial grants such as Internal Revenue Allotment, the extent of negative fiscal implication is "very great" $(M=4.12 ; S D=2.92)$ on first-class municipalities, $(M=4.12 ; S D=2.98)$ on second class; $(M=3.26$; $\mathrm{SD}=2.16)$ on $3^{\text {rd }}$ class; $4^{\text {th }}$ class municipalities $(M=2.49 ; S D=1.09)$ all interpreted "very great". Generally, findings revealed that higher classed municipalities exhibited a bit higher collection efficiency. However, it is still very low. Higher-classed municipalities provide higher budget appropriations for tax campaigns, more personnel, and updated property records consistent with the study of Slack and Bird (2015) that property taxation relies on adequate budget, secure and registered legal rights to land, and reliable property records. Plimmer and McCluskey (2016) found that an efficient and effective property tax administration comprises data on the real properties and individual taxpayers to be taxed and the use of technological resources. These findings of both groups of authors, Slack and Bird (2015) and Plimmer and McCluskey (2016), explained the very low collection efficiency of municipalities, which is contributory to a "very great" negative extent of fiscal implication to the collection of real property taxes. An examination of the records on collections in the Office of the Provincial Treasurer do not reconcile with the records of the Register of Deeds on transfers of ownership. The DAR revealed cancellations of CARP-issued titles, which corroborate the study of De los Reyes (2016), who discovered that $80.68 \%$ of issued titles were cancelled and reverted to the landowners, and $10.83 \%$ were cancelled in favor of another agrarian beneficiary. Hence, records of ownership are unreliable, a major difficulty for the collection of the property tax. De los Reyes (2016) found no clear guidelines on identifying beneficiaries of the CARP, similar to the findings of this study. 
The mechanism adopted by the DAR in the implementation of the retention limit where landowners choose the areas they shall keep resulted in the abandonment of the lands or leasing lands to other persons resulting in the dispossession of land, no payment of amortization of the lands to Land Bank of the Philippines (LBP) and no payment of real property taxes which contributed to a very great negative fiscal implication on collections of real property taxes by LGUs as found in this study. Another mechanism adopted by the DAR is voluntary land transfers (VLT) that contributed to higher collection delinquency. Borras (2005) found that VLT used paper beneficiaries who are either family members, "dummies," tenants and farm workers, or people completely unaware of the transaction. This finding is affirmed when notice of assessment from the Assessor's Office remains unclaimed when sent to the office of the barangay council for distribution because they do not know the persons named on the notices and are not residents of the barangays. Hence, these properties remain delinquent for a number of years, and these cannot be sold at public auction because the requisite of receipt of the notice of sale cannot be undertaken. Further, the non-payment of taxes results from the perceptions of unfairness or inequity, like failure to link the tax paid to services received from the government (Plimmer \& McCluskey, 2016).

Higher-classed municipalities can better provide good roads, communication facilities, and facilities and utilities to their constituents. This justifies why first-class municipalities revealed a little higher collection efficiency than lower classed municipalities articulating the benefit principle of taxation.

Size of covered areas. In terms of size of areas covered by CARP, which is the total number of hectares of lands issued with the notice of coverage by DAR classified as a bigger area which is more than 5,000 hectares while the smaller area is less than 5,000, as shown in Table 2, the results showed that for bigger and smaller areas, the implications are "very great" which means that the fiscal implications of CARP policies are significantly substantial to the RPT collections. Findings revealed that the highest percentage of agricultural land covered by the agrarian program was $87.96 \%$ in 2018; however, the collection efficiency was surprisingly only $2.92 \%$. This is strongly supported by the studies of Borras (2005), Borras (2007), and Ballesteros et al. (2017) on the mechanism adopted by CARP on VLT and VOS, which usually faked distribution via paper sales and use of beneficiaries who are either family members, heirs that are non-tillers, or persons having no interest on farming. The average percentage of agricultural lands covered by the CARP in the province is $39.52 \%$ until the fiscal year 2018. It was uncovered that areas covered by CARP for the years 2014-2018 have not been increasing; instead, some have shown a decrease. The study acknowledged Ballesteros et al. (2017) that the regions with the highest percentage balance as to scope are Region V, the Negros Island Region (NIR), where the province is a part, and Autonomous Region of Muslim Mindanao (ARMM). Likewise, de los Reyes (2016) revealed that as of December 2016, which was the end of the completion of the land distribution component of the CARP, an area of 603.2060 hectares remained undistributed, where $1 / 3$ of this balance as to scope comprising of farms above 50 hectares are located in Region VI and ARMM.

Land classification. When areas were grouped by classification as sugarland, riceland, and others, the extent of the fiscal implication of agrarian reform policies to the collection of real property taxes resulted to a "very great negative extent." The collection efficiency on all land classification covered by the agrarian reform program in all the municipalities of the province turned out below the standards of the BLGF, DOF. The findings imply that whatever is the land classification, the collection efficiency is very low, registering a very great negative fiscal implication of the agrarian policies to the RPT collection of municipalities. The findings find support in the studies of Borras (2005), de los Reyes (2016), Ballesteros et al. (2017), and Lanzona (2019) that there is still inequality in land ownership because the land is redistributed to former landowner elites because of the arrangement allowed by the DAR, one of the reasons why only $39.52 \%$ of agricultural lands in Negros Occidental was covered by the program in more than 20 years. Land distribution was slow for private agricultural lands, other than rice and corn lands under compulsory acquisition (Isaac, Carranza, \& Aceron, 2017). Lands planted to sugarcane, coconut, and other tree crops are the most problematic (Balisacan, 2007). Agri-business venture arrangements are cooperatives, leaseback, growership, productionprofit-sharing (PPS), and block farming believed to violate agrarian reform ideals (Tadem, 2015). These arrangements are beyond the reach of real property taxation. Cooperatives are exempt from 
taxation. In other arrangements, property owners cannot be identified, beneficiaries do not possess their lands, and those who are managing the lands cannot be taxed because real property taxes are levied to property owners only.

Table 1. Extent of fiscal implication of agrarian reform policies to the RPT collection of the municipalities

\begin{tabular}{lccc}
\hline Variable & M & SD & Interpretation \\
\hline Income classification & & & \\
1st Class & 4.12 & 2.92 & Very Great \\
2nd Class & 4.12 & 2.08 & Very Great \\
3rd Class & 3.26 & 2.14 & Very Great \\
4th Class & 2.49 & 1.09 & Very Great \\
Size covered & & & \\
Smaller (below 5,000 hectares) & 3.21 & 1.77 & Very Great \\
Bigger (5,000 hectares and more) & 3.94 & 2.77 & Very Great \\
Land classification & & & \\
Sugarland & 5.16 & 5.94 & Very Great \\
Riceland & 5.40 & 9.10 & Very Great \\
Others & 3.72 & 3.94 & Very Great \\
As a Whole & 4.68 & 6.23 & Very Great \\
\hline
\end{tabular}

\section{Difference in the extent of fiscal implications of the agrarian reform policies to RPT collections of the municipalities}

Tables $2 \mathrm{~A}$ and $2 \mathrm{~B}$ present the difference in the extent of fiscal implications of the agrarian reform policies to RPT collections of municipalities.

Kruskal Wallis was used to determining the difference in the extent of fiscal implications of the CARP to RPT collections when municipalities were grouped according to income classification, size of the area covered, and land classification. There was no significant difference in the extent of the fiscal implication of the CARP when municipalities were grouped according to income classification $[x 2(3)=6.970, p=0.073]$. This finding means that the collection efficiency from agrarian covered properties below $85 \%$ is a very great negative fiscal implication on collections of taxes regardless of the income of the municipality. This is explained by the fact that the province is predominantly agricultural. The majority of the people are engaged in farming because there are too few alternatives outside of agriculture.

As to the size of the area covered by the CARP, no significant difference was found in the extent of the fiscal implication of the agrarian policies to the RPT collections of the municipalities. Findings revealed that whether the area covered is big or small, the fiscal implications are negatively very great. As emphasized in the study of Fjeldstad et al. (2017), property tax is a tax on wealth borne by middle and high-income earners. Agrarian beneficiaries are among the marginalized sectors of society, but the awarding and distribution of lands enable them to acquire wealth; hence, they are expected to contribute by paying taxes to the government. However, the contrary prevailed because their attitudes have not changed (Fjeldstad et al., 2017). Since the property tax is highly visible to taxpayers, and in principle, is linked to improved local services (Fjeldstad et al., 2017). Still, since lands covered by the agrarian program are located in rural areas, the government's services are far less convenient than in the urban areas negating the benefit principle of taxation.

However, when municipalities are grouped by land classification, a significant difference was found $[\times 2(2)=9.761, p=0.008]$ with land classifications identified "others" providing lower negative fiscal implications than sugar land and rice land. This is because "other land classifications" are 
devoted to planting fruit trees, corn, and other crops, in possession of the registered owners and small areas only. These property owners realized income from the land classification "others"; hence, they can pay property taxes because they are in small amounts considering lower market valuation, which explains the significant difference.

Table 2A. Difference in the extent of fiscal implication of agrarian reform policies to the RPT collection of the municipalities

\begin{tabular}{lcccc}
\hline Income classification & $\mathrm{M}$ & $\boldsymbol{\chi}^{2}$ & $\mathrm{df}$ & $\mathrm{p}$ \\
\hline 1st Class & 4.12 & & & \\
& $(2.92)$ & & & \\
2nd Class & 4.12 & & & \\
& $(2.08)$ & & & \\
3rd Class & 3.26 & 6.970 & 3 & 0.073 \\
& $(2.14)$ & & & \\
4th Class & 2.49 & & & \\
& $(1.09)$ & & & \\
Land classification & & & & \\
Sugarland & 5.16 & & & \\
& $(5.94)$ & & & \\
Riceland & 5.40 & & & \\
& $(9.10)$ & & & \\
Others & 3.72 & & & \\
& $(3.94)$ & & \\
\hline
\end{tabular}

Note: The difference is significant when $p \leq 0.05$

Table 2B. Difference in the extent of fiscal implication of agrarian reform policies to the RPT collection of the municipalities

\begin{tabular}{llcc}
\hline Size covered & $\mathrm{M}$ & $\mathrm{U}$ & $\mathrm{p}$ \\
\hline Smaller & 3.21 & & \\
& $(1.77)$ & & \\
Bigger & 3.94 & 1014.500 & 0.410 \\
& $(2.77)$ & & \\
\hline
\end{tabular}

Note: The difference is significant when $p \leq 0.05$ 


\section{Relationship between the extent of fiscal implication of the agrarian policies to RPT collections of municipalities and the size of the area covered by CARP}

Table 3 presents the relationship between fiscal implications of the agrarian reform policies to the RPT collections and the size of the area covered by CARP.

Spearman rank correlation was used to determine the relationship between the extent of the fiscal implication of the agrarian reform policies to RPT collections of municipalities and the size of the area covered. There is a significant relationship between the fiscal implications and the size of the area covered by the CARP $[\rho(93)=0.239, \mathrm{p}=0.20]$.

The significant inverse relationship implies that, as the area covered by CARP increases, collection efficiency decreases, which means that the fiscal implications become greater. The interpretation of this relationship is that the longer the CARP is implemented, the agrarian reform beneficiaries became adaptive to the mechanisms employed. They have adjusted to the policies of the CARP (Elvinia, 2011). The local government is too lenient to implement tax regulations (Cruz \& Cruz, 2018). Sometimes, they resorted to condonation of interests and penalties instead of sale at public auction because requirements cannot be complied with by local treasurers associated with policies of the CARP. This is a regressive effect of fiscal policies also found in studies of Hesmati, Kim, and Park (2014), Joumard, Pisu, and Bloch (2012), the International Monetary Fund (2013), and OECD (2012).

Table 3. Relationship between fiscal implications of agrarian policies to the RPT collection of municipalities and size of area covered by CARP

\begin{tabular}{lrrr}
\hline Variable & $\rho$ & df & $p$ \\
\hline Fiscal implication $x$ size of area covered & $0.239^{*}$ & 93 & 0.020 \\
\hline Note: ${ }^{*}$ The correlation is significant when $p \leq 0.05$. & & &
\end{tabular}

\section{Challenges encountered by local treasurers}

Challenges encountered by treasurers are presented in Table 4. There are challenges identified by $100 \%$ of respondents affirming agrarian studies: insufficient appropriations (Plimmer \& McCluskey, 2016; Drbohlav et al., 2017), lack of personnel and property owners cannot be located (de la Cruz, 2015; Elvinia, 2011; Guevarra, 2004; Ballesteros et al., 2017) including insufficient facilities for use in the tax collection program, and lack of transportation to reach far and mountainous barangays. There are three challenges identified by category: poverty, weak enforcement of administrative remedies, and social acceptability, implying the deficiency of governance at all levels.

Challenges encountered directly resulting from policies and mechanisms adopted by the agrarian program: issuance of CLOAs, lack of sufficient information on property owners, legal cases over the property, properties subject of a lease, agrarian properties excluded from auction, poverty, inequitable valuation, names of beneficiaries are not authentic, conflict of ownership and lack of social acceptability of taxation of CARP covered properties. These challenges are an affirmation of the studies of Llanto and Ballesteros (2003), Ballesteros et al. (2017), Borras (2005), de los Reyes (2016), Elvinia (2011), LAMP-PMO (2003), de la Cruz (2015), Ballesteros (2010), Palic (2014), Tadem (2015), Limbo (2017), Lanzona (2019), and Goño (2019).

There are outcomes of agrarian policies resulting from the non-land transfer scheme revealed in the study of Elvinia (2011) and Ballesteros et al. (2017) that DAR does not maintain a database and does not provide LGUs of properties covered by stock distribution options on sugar farms similar with the findings of this study. The adoption by DAR of the agribusiness venture arrangements (AVAs) such as block farming and cooperatives to a very great extent negatively impact the RPT collections of municipalities. Another mechanism that weakens the collection efficiency of LGUs is the land valuation and owners' compensation (Adriano, 2013) because there is no standard valuation; hence, challenged by landowners before the courts and treasurers cannot collect taxes on properties subject of litigation. 


\begin{tabular}{|c|c|c|}
\hline Challenges & $f$ & $\%$ \\
\hline \multicolumn{3}{|l|}{ Income classification } \\
\hline Insufficient appropriations for tax collection program & 19 & 100 \\
\hline Lack of personnel & 19 & 100 \\
\hline Inadequate technical knowhow & 15 & 79 \\
\hline Poverty & 15 & 79 \\
\hline Weak enforcement of remedies & 11 & 58 \\
\hline Social in-acceptability of taxation of CARP & 10 & 53 \\
\hline Voluminous administrative requisites & 10 & 53 \\
\hline Inadequate professional competence of implementers & 9 & 47 \\
\hline Ineffective monitoring & 6 & 32 \\
\hline Political intervention & 5 & 26 \\
\hline Limited use of information technology & 5 & 26 \\
\hline Lack of appropriate strategies & 5 & 26 \\
\hline Lack of public awareness & 4 & 21 \\
\hline Corruption & 3 & 16 \\
\hline \multicolumn{3}{|l|}{ Size covered } \\
\hline Property owners cannot be located & 19 & 100 \\
\hline Lack of transportation to mountainous barangays & 19 & 100 \\
\hline Lack of personnel & 19 & 100 \\
\hline Tax declarations on (CLOA) & 17 & 89 \\
\hline Barangay officials do not cooperate & 16 & 84 \\
\hline Insufficient information & 16 & 84 \\
\hline Poverty & 15 & 79 \\
\hline Weak enforcement of administrative remedies & 11 & 58 \\
\hline \multicolumn{3}{|l|}{ Lack of social acceptability } \\
\hline Conflict of ownership & 7 & 37 \\
\hline School officials do not cooperate & 6 & 32 \\
\hline Inequitable valuation & 5 & 26 \\
\hline Names of beneficiaries are not authentic & 4 & 21 \\
\hline \multicolumn{3}{|l|}{ Land classification } \\
\hline Excluded from the auction & 17 & 89 \\
\hline Legal cases filed & 16 & 84 \\
\hline Poverty & 15 & 79 \\
\hline Properties subject of the lease & 14 & 74 \\
\hline Weak enforcement of administrative remedies & 11 & 74 \\
\hline Lack of social acceptability & 10 & 53 \\
\hline Multiple taxations & 7 & 37 \\
\hline
\end{tabular}

The identification of poverty as one of the challenges encountered by local treasurers in the collection of taxes is supported by studies of Spoor (2012), Borras et al. (2009), Balisacan (2007), and Ballesteros (2010), which redound to very great negative implication to the collection of the LGUs.

Generally, the challenges faced by local treasurers are both administrative and technical in nature arising from the implementation of the policies and mechanisms of the agrarian program which cannot be resolved at the local level alone. To overcome these challenges on collections of real property taxes by LGUs, and for the agrarian program to succeed, there is a need for collaborative efforts or the whole-of-governance approach where the government agencies (national and local), civil society organizations, lawmakers, and the citizens should participate. Hence, the optimal theory of taxation shall include the benefits and equitability principles espoused by the researcher as supported by robust evidence found in this study.

\subsection{Conclusion}

Many of the policies of the CARP have negative fiscal implications for local governments, supporting the theory of this study. Its impact is to a "very great" extent as far as collections of 
real property taxes. This implies that the LGUs are at the losing end, considering that problems arising from agrarian conflict are brought before the local governments for resolution, and services are expected to be delivered by the LGUs to agrarian reform beneficiaries. Therefore, the theory of optimal taxation focus on distributive justice is valid. The inclusion of the benefit and equitability principles will add to new knowledge on property taxation.

The identification of poverty as one of the challenges encountered by local treasurers revealed the failure of the approach adopted by the agrarian reform program. The billions of pesos lost to the CARP in terms of real property taxes deserve the lawmakers' attention at all levels of governance. These funds should have been used to provide a livelihood, infrastructure, and social services such as health and education.

The desire of this study to narrow the fiscal implications through the enhanced revenue generation strategies proposed for adoption using a basis the findings of this study.

\section{REFERENCES}

Adriano, F. (2013). Sustaining the momentum of inclusive growth in the post-carp Scenario. Integrative Report submitted to the InterAgency Committee on Institutional Arrangements for Land Management and Rural Development.

Bakibinga, D. \& Ngabirano, D. (2019). Enhancing Property Rates Administration, Collection and Enforcement in Uganda: The Case of Kampala Capital City Authority (KCCA) and four other Municipalities, ATAP Working Paper 13, Brighton, IDS

Balisacan, Arsenio. (2007). Agrarian Reform and Poverty Reduction in the Philippines.

Ballesteros, M. (2010). The Cost of Redistributive Land Reform in the Philippines: Assessment of PD 27 and RA 6657 (CARL) Discussion Paper Series No. 2010-09. Retrieved from https://pidswebs.pids.gov.ph/ris/dps/pidsdps1009.pdf

Ballesteros, M. M., Ramos, T.P., \& Ancheta, J. (2017). The Comprehensive Agrarian Reform Program after 30 Years: Accomplishments and Forward Options. Discussion Papers DP 2017-34. Philippine Institute for Development Studies.

Borras, S. (2005). Can Redistributive Reform Be Achieved via Market-Based Voluntary Land Transfer Schemes? Evidence and Lessons from the Philippines, Journal of Development Studies 41(1), 90-134.

Borras, S. M. Jr. (2007) "Pro-poor Land Reform: A Critique," Ottawa: University of Ottawa Press. ISBN 9780776617718.

Borras, S. M., Carranza, D., Franco, J.C., \& Manahan, M.A. (2009). Anti-land Reform Land Policy? The World Bank's Development Assistance to Agrarian Reform in the Philippines. Quezon City: Focus on the Global South-Philippines.

Cruz, A.L, \& Cruz, F.J. (2018). Assessing the Revenue Raising Capacity of the Local Government of Bongabon in the Philippines. Journal of Public Administration and Governance, ISSN 2161-7104, 2018, Vol. 8, No. 3.

Cvjetkovic, Cvjetana, Veselinovic, Janko, \& Nikolic, Ivica. (2015). Tax treatement of farmers in the Republic of Serbia. Ekonomika poljoprivrede. 62. 737-749. 10.5937/ekoPolj1503737C.

De la Cruz, R. (2013). Real Property Taxation on Agrarian Reform Covered Properties in Don Salvador Benedicto. University of Negros Occidental-Recoletos, Bacolod City.

De los Reyes, V. (2016). End of term report of Secretary Virgilio de los Reyes: for the term from July 2010 - June 2016. Department of Agrarian Report.

Dimopoulos, Thomas. (2015). Theories and philosophy of property taxation. REVIEW OF DECENTRALISATION, LOCAL GOVERNMENT, AND REGIONAL DEVELOPMENT. 2015. 101.

Drbohlav, P., Svitálek, J., \& Hejkrlík, J. (2017) "Socio-economic Assessment of the Philippine Agrarian Reform," AGRIS on-line Papers in Economics and Informatics, Vol. 9, No. 2, pp. 33 - 46. ISSN 1804-1930. DOI 10.7160/aol.2017.090203.

Elvinia, J. (2011). Is land reform failure in the Philippines? An assessment on CARP

Endriga, V. (2004). The Roadmap to Financial Stability: The Experience of Quezon City. Manila, Philippines.

Fjeldstad, O., Ali, M., \& Katera, L. (2017). Property Taxation in Developing Countries. CMI Brief. 16. Bergen: Chr. Michelsen Institute (CMI Brief vol. 16 no. 1) $4 \mathrm{p}$.

Goño, C. C. (2019). Agribusiness contracts after property rights reforms. Manila, Philippines: National Historical Commission of the Philippines

Goodfellow, T. (2016). Property taxation and economic development: Lessons from Rwanda and Ethiopia. SPERI. https://www.ictd. ac/publication/property-taxation-and-economic-development-lessons-from-rwanda-and-ethiopia-new-global-politicaleconomy-brief-from-speri/

Government of the Philippines (1988) "Republic Act No. 6657. An Act Instituting a Comprehensive Agrarian Reform Program to promote social justice and industrialization, providing the mechanism for its implementation, and other purposes." [Online]. Available: http://www.dar.gov.ph/ra- 6657-what-is-carp-comprehensive-agrarian-reform-program [Accessed: 14 Jan. 2017].

Government of the Philippines (1991). Republic Act No. 7160. The Local Government Code of the Philippines of 1991.

Guevara, M. (2004). "Real Property Taxation in the Philippines," Chapters, in Richard M. Bird \& Enid Slack (ed.), International Handbook of Land and Property Taxation, chapter 11, Edward Elgar Publishing.

Heshmati, A., Kim, J., \& Park, D. (2014). Fiscal Policy and Inclusive Growth in Advanced Countries: Their Experience and Implications for Asia. Asian Development Bank Economics Working Paper Series No. 422. Retrieved https://ssrn.com/abstract=2558908 or http://dx.doi.org/10.2139/ssrn.2558908

International Association of Assessing Officers. (2010). Standard on Property Tax Policy. http://www.iaao.org

International Monetary Fund (2013). REASSESSING THE ROLE AND MODALITIES OF FISCAL POLICY IN ADVANCED ECONOMIES. IMF Policy Paper

Isaac, F., Carranza, D., \& Aceron, J. (2017). From the Ground Up: Multi-Level Accountability Politics in Land Reform in the Philippines. Accountability Working Paper Number 2

Johnson, R., \& Kuby, P (2012). Elementary Statistics. Student Solutions Manual. Cengage Learning.

Joumard, I., Pisu, M., \& Bloch, D. (2012). Tackling Income Inequality: The Role of Taxes and Transfers. OECD Journal: Economic Studies. http://dx.doi.org/10.1787/eco_studies-2012-5k95xd6l65lt

Kaplow, Louis (2008a). The Theory of Taxation and Public Economics. Princeton University Press.

Lamela, J. (2018). The Agrarian Production Credit Program of the Department of Agrarian Reform in the 2nd Congressional District of Negros Occidental. (Unpublished master's thesis). University of Negros Occidental- Recoletos, Bacolod City 
LAMP-PMO Report. (2003), Supervision Mission, February 2003.

Lanzona, Jr. L., (2019). Agrarian Reform and Democracy: Lessons from the Philippine Experience. https://doi. org/10.1177/0976399619879866

Llanto, G.M., \& Ballesteros, M.M. (2003). Land issues in poverty reduction strategies and the development agenda: The Philippines

Limbo, R.C. (2017). Agribusiness Venture Arrangements (AVAs) in Agrarian Reform Areas in the Philippines: Identifying Alternative Schemes

Mcdonnel, S., Foukona, J., \& Pollard, A. (2011). Building a pathway for successful land reform in the Solomon Islands.

Mirrlees, James A. (1971). "An Exploration in the Theory of Optimal Income Taxation," Review of Economic Studies 38, 175-208.

Plimmer, F. \& McCluskey, W.J. (2016). Property Taxation for Developing Economies. FIG Commission 9 - Valuation and the Management of Real Estate. FIG Publication No. 67. UN-Habitat. Retrieved https://www.fig.net/resources/publications/ figpub/pub67/Figpub67.pdf

Rajaraman, Indira. (2005). Taxing Agriculture in a Developing Country: A Possible Approach. Contributions to Economic Analysis. 268. 245-268. 10.1016/S0573-8555(04)68812-2.

Ramsey, Frank. (1927). "A Contribution to the Theory of Taxation," Economic Journal, 37, (March), 47-61.

Sauer, S. (2009). Market-led "agrarian reform' in Brazil: A dream has become a debt burden. Progress in Development Studies, 9(2) 127-140. doi:http://dx.doi.org/10.1177/146499340800900204

Slack, E. \& Bird, R. (2015). How to Reform the Property Tax: Lessons from around the World. IMFG Papers on Municipal Finance and Governance.

Soliwoda, Michał \& Pawłowska-Tyszko, Joanna. (2015). Income taxation in agriculture vs. competitiveness. International perspective and evidence from Poland. Journal of the Austrian Society of Agricultural Economics. 25. 211-220.

Spoor, M. (2012). Agrarian reform and transition: what can we learn from 'the east'? The Journal of Peasant Studies, 39:1, 175-194, DOI: $10.1080 / 03066150.2011 .652949$

Tadem, E. (2015). Philippine Agrarian Reform in the $21^{\text {st }}$ Century. Discussion Note No. 2. An International Academic Conference. Chiang Mai University.

UN-Habitat (2011). Innovative Land and Property Taxation. United Nations Human Settlements Programme. https://issuu.com/ unhabitat/docs/innovative_land_and_property_taxation

Villaroman, L. (2017). Factors Affecting Collection of Real Property Tax in the Provincial Treasurer's Office of Nueva Ecija. Retrieved https://ssrn.com/abstract=3093130or http://dx.doi.org/10.2139/ssrn.3093130

\section{Correspondence:}

SHARON M. ZARAGOZA

shawie_z@yahoo.com

https://orcid.org/0000-0001-8528-8610

MERLITA V. CAELIAN

merlita_caelian@yahoo.com

https://orcid.org/0000-0002-4671-4047 